\title{
Long Roads to Ludlow
} Elizabeth Jameson - University of Calgary

Thomas G. Andrews, Killing for Coal: America's Deadliest Labor War (Cambridge, MA: Harvard University Press, 2008).

Ronald G. Lewis Welsh Americans: A History of Assimilation in the Coalfields (Chapel Hill, NC: University of North Carolina Press, 2008).

Killing for Coal and Welsh Americans, both published in 2008, chronicle the history of coal mining in the United States from distinct vantage points. Thomas Andrews focuses on the environments and culture that linked fossil-based energy to industrial society and labour relations, Ronald Lewis on the influence of Welsh miners on the US coal industry, their upward mobility and ultimate assimilation. Despite the title, Killing for Coal is considerably broader in scope than the epic 1913-1914 strike of the United Mine Workers of America (UMW) in the southern Colorado coalfields that climaxed with the event known as the Ludlow Massacre. Yet both books end at Ludlow. In this essay, I compare their respective contributions to the histories of US coal mining labour. It is useful first briefly to review the history of their common final chapters.

The 1913-1914 strike is popularly remembered through the deaths of eleven children and two women who suffocated on April 20,1914 in the "death pit" cellar in which they sought refuge as the miners' Ludlow tent colony burned. At Ludlow, one of the tent colonies that the UMW erected to house miners evicted from company housing, miners and their families representing more than twenty ethnicities cooperated in camp governance and leisure as they waged a seven-month strike against mining corporations, the largest of which was the Rockefeller-controlled Colorado Fuel and Iron Company (CF\&I). They struck for union recognition, a ten-percent increase in tonnage rates, the eighthour day, pay for "dead" work, check-weighmen elected by the miners, the right to board and buy where they chose and to select their own doctors, the enforcement of Colorado mining laws, and an end to the system of mine guards that had enforced company rule in southern Colorado coal camps. The Ludlow Massacre ignited ten days of literal class warfare until President Woodrow Wilson sent in US troops. The southern coalfields had for decades been torn by violence underground and in repeated clashes between Colorado miners, miner owners, and the state. Until Ludlow, all the casualties had been men. Ludlow entered public memory as labour and progressive supporters focused public attention on the women and children who died there. In 1918 the UMW dedicated a monument at Ludlow to the union women, men, and children who died 
20 April 1914, and has held an annual commemoration there ever since. Labour historians remember Ludlow as well for prompting John D. Rockefeller to initiate company unions at the urging of industrial consultant and future Prime Minister Mackenzie King.

Andrews appropriately challenges popular memories that ignore the bloody battle after the Ludlow Massacre, and aims to displace the chronicle of a single day of industrial violence with a more complex narrative of the Ten Days' War and a much longer story of coal-based industrial society. For Ronald Lewis, Ludlow represents the anti-climax to a history of Welsh colliers' upward mobility and assimilation in the US coal industry. From these divergent perspectives of environmental and ethnic history, Lewis and Andrews offer sometimes-complementary windows on class formation and industrial social relationships.

Welsh Americans offers a geographically broader scope that only ends in Colorado, and a narrower subject focus on Welsh immigrants and Welsh Americans who "were instrumental in establishing the American coal industry and in shaping it into the engine of the American industrial revolution" (ix). He seeks to end their historical invisibility. He locates his study in the transnational journeys of Welsh who migrated to America beginning in the $17^{\text {th }}$ century, but focuses primarily on the $19^{\text {th }}$-century migrations that led from the rural Welsh countryside to the rapidly developing iron industry and collieries of south Wales, and then to the United States, where immigrants transported their knowledge of underground mining and anthracite-fueled iron smelting.

Welsh miners were much fewer proportionately compared with other European immigrants, due to the expanding Welsh industrial economy. Nonetheless, Lewis argues, they exerted disproportionate influence as they brought their craft skills, industrial grievances, and their organizing experience to US collieries, and their technical expertise to the developing anthracite iron industry and the later use of coke in iron production. Lewis traces the careers of a number of Welsh immigrants who rose quickly to management and ownership in most major coal areas, and, particularly in the northern states, hired Welsh foremen and miners. He links US mine safety campaigns and labour organizing to Welsh and English campaigns to ban women and young boys from the mines, resist payment in scrip, promote arbitration, and form trade unions.

The Welsh who emigrated to the United States were drawn by egalitarian and democratic ideologies and tolerance for Nonconformist Protestant religions. Clustering in Welsh enclaves, they forged a mining culture rooted in the shared dangers of underground work, and interdependent ties of work, family, and ethnicity. For several generations they maintained Welsh culture and identity through their language, press, churches, family networks, fraternal orders, and cultural practices such as the Eisteddfod festival. Lewis uses evidence from the Welsh mining stronghold of Scranton, a sample of Ohio miners, county histories, and other sources to demonstrate considerable inter-generational occupa- 
tional mobility into semi-skilled occupations, and ultimately out of coal mining.

Only after establishing the cultural and industrial roots of the Welsh migrations to the coalfields and the geographic and occupational mobility of the first generations does Lewis return to the underground workings and their dangers, and to mine safety movements sparked, as in Britain, by mining disasters like the 1869 "Welsh Disaster" at Avondale, Pennsylvania, where Welsh miners predominated among the rescuers and the 110 dead. The Avondale tragedy led to a state mining law mandating two mine entrances, barring boys under twelve from working underground, and establishing mine inspectors, a profession in which many Welsh became prominent.

As the Welsh ascended the skill ladder and achieved supervisory and management positions, other immigrants took the less skilled jobs underground. Lewis traces ethnic conflicts in the coalfields to Welsh animosity toward the Irish migrants who entered South Wales coalfields during the potato famine, sometimes as strike breakers, and who the Welsh feared would depress wages. That ethnic discord flared repeatedly in the United States as successive waves of immigrants entered the unskilled ranks underground. After the Irish came the southern and eastern Europeans, the rapid assimilation of the Protestant English-speaking Welsh, and their departure from the coalfields. By the early $20^{\text {th }}$ century, Lewis contends, few second-generation British sons followed their fathers underground, and a new mining culture emphasized common class values and interests to bridge ethnic differences.

If the Welsh exodus from the collieries was well underway by the $20^{\text {th }}$ century, individual Welshmen continued to influence the industry from positions of union leadership, represented most prominently in Welsh Americans by reform unionist David R. Jones; William T. Lewis of the Knights of Labor; his brother, Thomas L. Lewis, UMW president from 1909-1912; and, most famously, by John L. Lewis, UMW president from 1920-1960 and the founding president of the Congress of Industrial Organizations (CIO). Lewis does not deal with Welsh organized labour in any detail, focusing rather on the reformist orientation of a few prominent leaders, and their roots in Welsh American communities. Here the narrative devolves to a chronicle of famous Welsh labour leaders, and while there are interesting tidbits about John L. Lewis's Welsh Mormon background, which he preferred to hide, there is scant material to link Welsh identity with $20^{\text {th }}$-century labour organization.

Lewis concludes with the 1913-1914 Colorado coal strike, told from the unique but appropriate perspective of one Welsh woman, Mary Thomas. Lewis bases much of the chapter on Thomas's testimony to the Senate Commission on Industrial Relations, published in 1916, and her first-person account, Those Damned Foreigners, published in 1971, as well as respected labour histories like George McGovern and Herbert Guttridge's The Great Coalfield War (Boston: Houghton Mifflin Company, 1972) and Priscilla Long's Where the Sun Never Shines 
(New York: Paragon House, 1989). Mary Thomas came to Colorado in 1913 to make the husband who had abandoned her in Wales contribute to the support of their two daughters. She was a prominent union activist at Ludlow where she worked in the union canteen, provided child care, and was jailed as an agitator after a large demonstration of women (which she did not attend) to protest the arrest of Mother (Mary Harris) Jones. Thomas befriended women of diverse ethnic heritages, including Cedi Costa, who died with her children in the Ludlow death pit. After the strike, Thomas went on a union-sponsored speaking tour along with Mary Petrucci, who lost three children in the death pit, and camp nurse Pearl Jolly. She met with President Woodrow Wilson, picketed

Rockefeller's office with novelist Upton Sinclair, and later testified before the Senate Industrial Commission that investigated the strike. She went on to operate a dance hall to support her daughters, and then remarried and moved to Hollywood. For Lewis, Thomas represents increasing class-consciousness and diminished ethnic division in the coal fields, Welsh assimilation, upward mobility, and movement away from the coal camps.

Mary Thomas might also personify the version of Ludlow that Thomas Andrews seeks to dislodge, the story focused narrowly on a single day divorced from larger contexts and relationships that linked capitalists, consumers, and mining families with the natural world and from the "physical, biological, and cultural processes" that made the underground workings both dangerous and dynamic (16). To understand those linkages, Andrews suggests, requires connecting Ludlow to a half century of struggle between mine owners and their workers.

Most published histories place Ludlow in that longer context, and historians of western mining labour have long challenged the frontier myth of rugged individualism and opportunity. Andrews breaks new interpretive ground as he extends his analysis to nonhuman ecologies, to the intersections of physical, social, and economic power. His story thus has multiple starting points: the processes that formed Colorado's coal beds beginning some seventy million years ago; the transformation from solar-based agriculture to fossil-fuel based industry; the vision of William Jackson Palmer, who was inspired by coal-fired British industry to develop rail lines to Colorado and the coalfields that fed them; and the migrations that drew labour from all corners of the earth. Andrews then links the class inequalities that developed in the mines and smelters of Colorado's Front Range with the unequal environmental impacts of industrialization that ranged from the health hazards of mining and smelting, to arid lands made profitable by coal-powered irrigation and railroads, to middleclass homes and wealthy urban neighbourhoods made more comfortable by the heat, light, and transportation that coal and gas provided.

The workforces that made all this possible included Hispanos recruited from New Mexico and southern Colorado, eastern coal miners, and Europeans 
and Asians responding to economic, environmental, and demographic changes as new methods of agriculture, sanitation, garbage disposal, disease prevention, and social regulation led to expanding populations. As in Wales, coal pushed people from some places and drew them to others; they often journeyed to Colorado collieries aboard coal-powered steamships and railroads. Andrews asks how this diverse and mobile population came to make common cause in the strikes that rocked Colorado's coalfields beginning in 1884. He finds the answer underground, in the work environments he calls workscapes to connote "a place shaped by the interplay of human labor and natural processes" and to assert that "wherever people work ... the boundaries between nature and culture melt away."

Geology shaped these spaces, and conditioned the ways that humans could work them, from the depth and breadth of a coal seam to the dust and gas that made coal mines precarious workscapes indeed. Those dangers were magnified by management practices like payment by the ton which made tasks like timbering that enhanced safety unprofitable "dead work." Environmental dangers and capitalist mining practices combined to produce the mining disasters that united miners to organize unions, strike, and forge shared class identities. Andrews elides the history of ethnic divisions that, in Lewis' account, preceded shared class identities. Like Lewis, Andrews acknowledges the craft skill and history of mutualism that British miners brought to Colorado, but he lumps together as "British" the considerably more divided Welsh, Cornish, English, Scottish, and Irish miners. And unlike Lewis's upwardly mobile Welsh, Colorado colliers were more likely to be geographically mobile than to climb the class ladder.

Andrews traces miners' organizing to the dangers and limited rewards of mining, and to contracting opportunities. He links the geography of organizing to the geography of power in company coal towns where mining companies owned the homes and meeting halls and increasingly organized the town geography and social institutions to monitor and influence miners' associations. Coal companies constructed homes, stores, schools, and clubs to promote individualism, consumerism, and Americanism. Miners contested the geography of power dramatically in the colliers' marching strike in 1894, as they met outdoors and in saloons, and marched from camp to camp throughout southern Colorado. That ultimately unsuccessful strike coincided with the successful strike of Cripple Creek gold miners the same year. Significant strike waves occurred again in the Colorado coal and hardrock camps in 1903-1904 and in the southern Colorado coal strike of 1913-1914. Andrews locates the 1913-1914 strike and the owners' responses in this long history of industrial conflict, in which mine owners retained power with the help of paid detectives and state troops. The strike, Andrews might have noted, again contested the geography of power as the union strategically placed its tent colonies at the mouths of canyons that led to the coal camps in order to impede the importation of strike breakers. Yet it 
ended with a system of corporate paternalism that left miners no place, either at the bargaining table or on the land.

In a powerful epilogue, Andrews links the Coalfield War to the current energy wars in Nigeria, Venezuela, Bolivia, and Iraq, and suggests that we should ask "more probing questions about our connection with these conflicts and our responsibility for the suffering and damage they are causing." (290) A more holistic historical vision, he suggests, might help us understand the linked environmental, social, economic, and political aspects of current problems like climate change, poverty, war, and pollution. This seems undeniable in the wake of the British Petroleum disaster in the Gulf of Mexico.

Andrews offers a powerful narrative for this current context in his ambitious and sophisticated history that links energy, the environment, and industrial labour relations. His model is likely to be emulated and refined by future historians. I am less convinced that either Andrews or Lewis significantly change previous histories of the Colorado Coal War or of industrial relations in the American collieries. Lewis's greatest contribution lies in the substantial connections that he charts between the Welsh and American collieries, adding a valuable piece of the ethnic puzzle to existing volumes on Cornish, Irish, Greek, and other mining populations. Regrettably, his substantial survey of sources on Welsh colliers did not include some of the Colorado sources that Andrews located. Lewis' chapter on Ludlow could have benefited contextually, for instance, from Andrews' accounts of some 500 Welshmen in Fremont County collieries, who, like their eastern counterparts, supported Methodist churches, singing societies, the Eisteddfod, and the Knights of Labor, and who led the first significant strike of Colorado coal miners in 1884.

Andrews in fact began his saga of miners' migrations to Colorado collieries with Mary Thomas, who appears in his account as a relatively affluent young bride rather than the class-conscious deserted wife of Lewis' concluding chapter. Here Andrews' narrative might have been strengthened by the literature on women in the British collieries that Lewis cited. Andrews appears also to make scant use of key histories of ethnic migration to the coalfields, like Sarah Deutsch's No Separate Refuge (New York: Oxford University Press,1987) and Gunther Peck's Inventing Free Labor (Cambridge: Cambridge University Press, 2000), or of histories of mining labour that he cites but does not use extensively, and even standard sources on Rocky Mountain saloons. These lead to gaps in the linked histories of Colorado mining conflicts, like the role of Ludlow militia commander John Chase in the 1903-1904 miners' strikes, which help explain why the miners armed themselves in 1914. These would only further strengthen Andrews' emphasis on the long history of Colorado mining conflicts in which Ludlow was located.

More significantly, Andrews' focus on the environment of the workscape seems at times to undercut the miners' own understanding of their 
grievances, which they blamed squarely on capitalist mine owners. For instance, Andrews asserts that unions "succeeded in organizing the southern collieries only insofar as they could build on the pride, independence, solidarity, and understanding of masculinity forged in the daily struggle between mineworkers and their workscapes" (175). The 1913-1914 strike began, he contends, in "the mine workscape” (261). Working conditions underground certainly bred miners' grievances and fostered a work culture of solidarity. The miners did not blame the mines for their dangers, however; they blamed the owners for unsafe conditions and unfair compensation. In an illuminating footnote, Andrews suggests that "an emphasis on energy systems instead of modes of production can perhaps help account for some of the common failings of capitalist and Communist regimes over the course of twentieth-century history." It is a comment that begs to be amplified. Andrews persuades me that we can usefully connect energy systems and modes of production. I doubt that he could persuade the striking coal miners in 1914 that the mode of production in which they laboured was less significant than the energy system their labour supported or the workscapes in which they toiled.

All quibbles aside, both these volumes make valuable contributions to histories of mining, labour, and industrial social and economic relations. Welsh Americans augments existing literature on ethnicity in American coal mining, adding the essential stories of Welsh miners to the complex ethnic mosaic of the US coalfields. Killing for Coal breaks new analytical ground to inform histories of mining labour, energy, the environment, and the American Left.
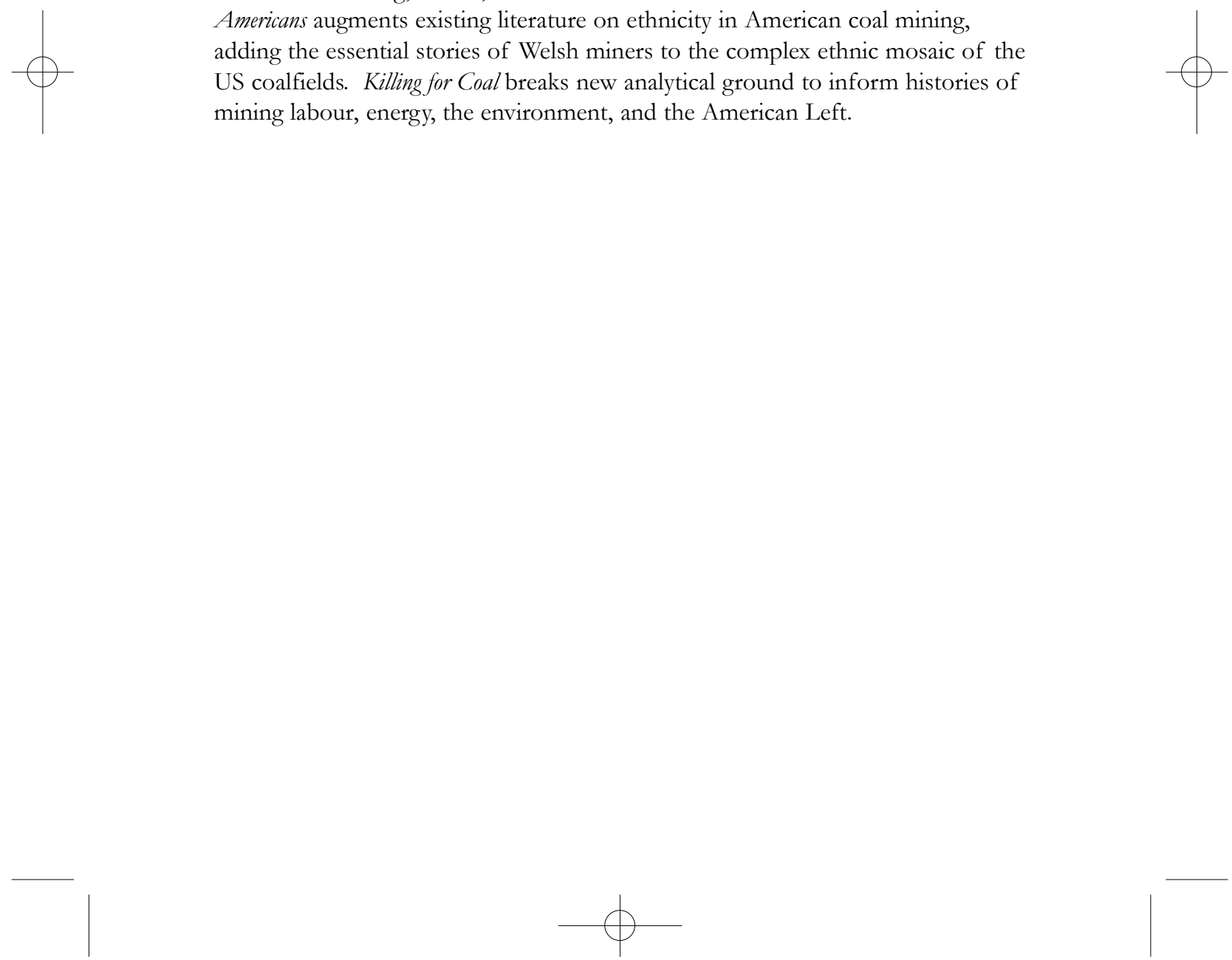


\section{LABOUR/LE TRAVAIL}

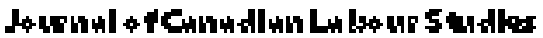

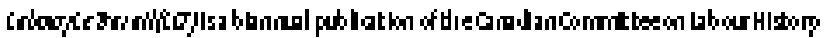

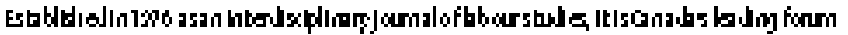

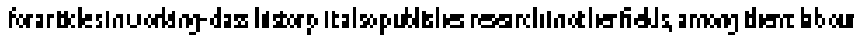

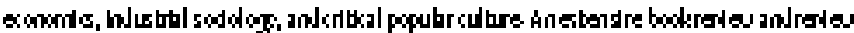

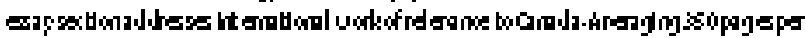

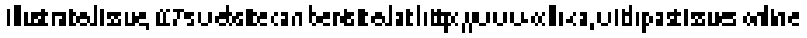
atuulatyoumata

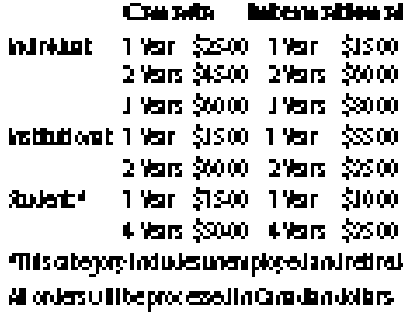

\section{CARADAR COMNTTEE OA LABOUR HETORY}

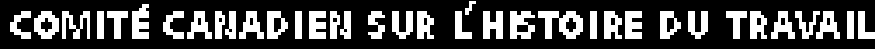

\section{LABOUR/LE TRAVAIL}

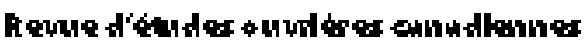

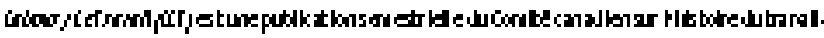

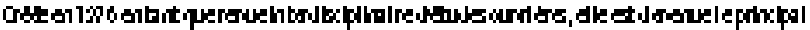

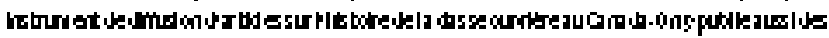

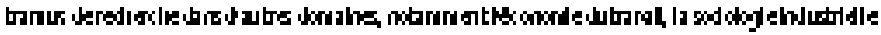

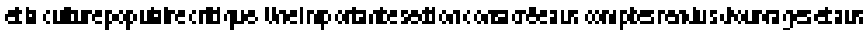

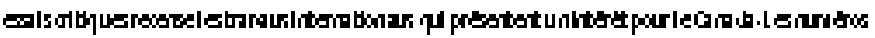

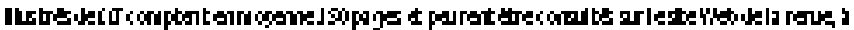

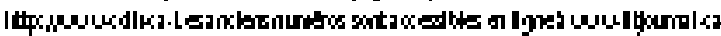

\begin{tabular}{|c|c|c|c|c|}
\hline \multirow[b]{2}{*}{ hartrua: } & \multicolumn{2}{|c|}{ DEA } & \multicolumn{2}{|c|}{ Mtemidis wad } \\
\hline & ומגו & 200 & והנו & 1500 \\
\hline & $2 a t 8$ & 4500 & $2 a t$ & $+\infty, 0$ \\
\hline & שו لـ & 0,00 & שוג لـ & 30,0 \\
\hline that Ist & ומגו & 1500 & ומנו & $s$ \\
\hline & $2 a t \varepsilon$ & 0,00 & $2 a t$ & 250 \\
\hline : & חנגו & 15005 & הנגו & 0,0 \\
\hline & 4ar & 30,05 & taic & \\
\hline
\end{tabular}

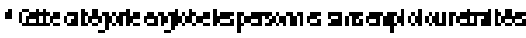

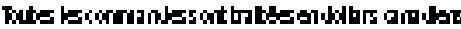

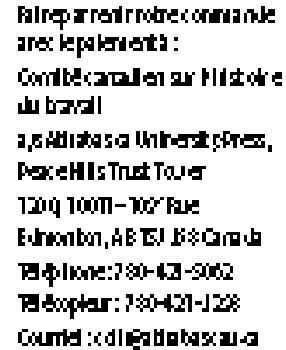

